\title{
Oil rent, entrepreneurial start-ups, and institutional quality: Insights from African oil-rich countries
}

\author{
Folorunsho M. Ajide, Kenny A. Soyemi
}

\begin{abstract}
A B S T R A C T
Objective: The objective of this study was to examine the moderating effect of institutional quality in the relationship between oil rents and entrepreneurial start-ups for oil-rich countries in Africa.

Research Design \& Methods: The study employed panel regression techniques that included instrumental variable (IV) estimator to analyse the data of 11 oil-rich countries in Africa over a period of 2006-2018.

Findings: The following results emerged. (1) Oil rent's impact is positive and significantly affects entrepreneurial start-ups. (2) The interactive coefficients of oil rents and institutional quality have a negative and significant impact on entrepreneurial start-ups. This means the quality of African institution reduces and leaks out entrepreneurial benefits of oil rents in African oil-rich countries. We establish that institutional quality's threshold at which oil rent would accelerate entrepreneurial start-ups is 2.23 on a five-point scale.

Implications \& Recommendations: This study revealed that the ability of oil rents to consistently promote entrepreneurial development in oil-rich economies depends on the level of institutional conditions. This situation may create a growth trap for African oil-dependent economies because entrepreneurial start-ups depend on the quality of institutional foundations, which may position the growth inclusiveness and government actions on the right paths. In this context, our empirical findings reveal that African governments need to work on the institutional quality of their economies to reduce the institutional curse of oil rents on African entrepreneurial start-ups.

Contribution \& Value Added: The article advances our understanding on the nexus of entrepreneurship and oil rents. It is the first study conducted on oil-rich countries in Africa. Moreover, the work differs from the literature by examining the threshold level at which African institutional quality would meaningfully enhance positive relationship between oil rents and entrepreneurial start-ups.

$\begin{array}{ll}\text { Article type: } & \text { research article } \\ \text { Keywords: } & \text { Africa; institutions; new business entry; oil rents; panel-corrected standard errors } \\ \text { JEL codes: } & \mathrm{M} 13, \mathrm{~N} 97, \mathrm{O} 43\end{array}$

Received: 16 March $2021 \quad$ Revised: 1 October $2021 \quad$ Accepted: 28 October 2021
\end{abstract}

\section{Suggested citation:}

Ajide, F.M. \& Soyemi, K.A. (2022). Oil rent, entrepreneurial start-ups, and institutional quality: Insights from African oil-rich countries. Entrepreneurial Business and Economics Review, 10(1), 35-49. https://doi.org/10.15678/EBER.2022.100103

\section{INTRODUCTION}

Many countries in Africa have recognized the value of entrepreneurship in job creation and sustainable growth in a bid to achieve sustainable development. This phenomenon motivated researchers and policy-makers in Africa, where several interesting regularities emerged. Firstly, researchers in this area largely focus on the impact of entrepreneurship on African growth (Adusei, 2016; Peprah \& Adekoya, 2020) with the neglect of institutional context in the relationship. Strong institutions offer entrepreneurs the means of attaining personal security and material welfare, which assist in lifting societies out of poverty. A country with good institutions has the tendency to experience sustainable growth and an equalitarian society with resultant impacts on every sector of the economy (Mobarak \& Karshenasan, 2012; Bustamante et al., 2020; Ajide \& Osinubi, 2020). 
Several channels through which these can happen include the strict rule of law, honesty and professionalism in business, reduction in transaction costs, and the timely provision of property rights. However, current developments reveal that economies - especially economies of the oil-rich countries - may be cursed by their institutions if the norms, beliefs, culture, and practices evolving within the countries lead to outcomes detrimental to most economic agents. Majbouri (2016) empirically reveals this by explaining that economies with oil rents may experience a decline in entrepreneurial start-ups because of rent-seeking behaviours appearing where the institutional quality is weak. Torres and Godinho (2019) further corroborate these findings by explaining that corruption control is key to attain an impressive level of innovative entrepreneurship in oil dependent countries. However, more research is needed to better learn whether the combination of oil rents and institutional conditions provide a blessing or curse for entrepreneurial development.

It is surprising that there is no study that empirically examines the role of institutions in the nexus of oil rents and entrepreneurship, despite the fact that most of economies in Africa depend on natural resources. This study aims to fill this important knowledge gap. Therefore, the objective of this article is to examine the impact of oil rents and its interaction with institutional quality on entrepreneurial start-ups in oil rich countries in Africa. The novelties of this article will be discussed as follows. Firstly, we will study the case of eleven selected African oil-rich countries. Studies reveal that economies with abundant natural resources have substantial high chances of growth in all sectors through entrepreneurial start-up activities and development, but the ability to realise this mission depends on how rents from the natural resources accruable to the economy are harnessed and utilised (Olayungbo \& Adediran, 2017; Ajide, 2021). Oil production and export play a significant role in these countries accounting for relatively $60-90 \%$ of gross earnings while the issues of resource and institutional curse has been an intense debate in the literature of these countries. More so, the majority of these countries have developed and embraced entrepreneurship policies. They focus on entrepreneurial start-ups and give support for the establishment of young dynamic firms with a potential to be the engine of sustainable growth and economic transformations. Governments of these countries are directing efforts to develop conducive entrepreneurial environment and emergence of new firms in general (Adusei, 2016; Kantis, et al., 2020). However, entrepreneurship data in these countries are relatively limited; making empirical studies of this nature relatively scarce (Kantis, et al., 2020). Our study relies on World Bank entrepreneurship data to fill this important literature gap.

In addition to the fact that these countries have either weak or poor quality of institution, we attempt to develop a relative threshold level at which these institutions would meaningfully enhance entrepreneurial start-ups via oil rents in the economy. This supports the explanation of Mobarak and Karshenasan (2012) who hint that institutional quality may change the orientation of entrepreneur as an innovator and in creating productive hub of an economy. Entrepreneurs may decide to consider rent seeking or engage in productive activities depending on how strong the underlining political structure and economic institutions of a nation are. In the same manner, the relative profitable engagement depends on rule of law and bureaucratic efficiency. Strong and efficient quality of institutions may lead an entrepreneur to an equilibrium to add values to the economy while low and inefficient institutions may lead them to be a rent-seeker. Abundant revenue from natural resource may lower the entrepreneurial start-ups, growth and national income of a country with poor institutional quality (Kolstad 2007; Mobarak \& Karshenasan, 2012; Majbouri, 2016). This means that oil rents interaction with institutions could be a source of blessing to an economy if the outcome is beneficial to entrepreneurial development, however, if the outcome is disadvantageous it could be a curse, especially when there are weak institutional qualities. Another contribution of this study has to do with the policy perspective. The article provides a clear-cut empirical policy direction for African economy as shared by United Nations' sustainable development goals (SDGs) aim at boosting growth, providing decent work and reducing poverty to zero level in the world through entrepreneurial ecosystem. This happens by achieving high level of productivity via entrepreneurial networks, innovative activities, and job creation by 2030. 


\section{LITERATURE REVIEW AND HYPOTHESES DEVELOPMENT}

\section{Oil rent in Africa}

Oil rent is described as return for ownership of oil resource, which is paid/payable to states that own it. Theoretically, Yates (2015) defines oil rent as revenue generated from a given petroleum products sold to consumers minus total cost of production, marketing activities, and transportation. Basically, this definition connotes oil rent as a surplus or excess income over total costs from initial exploration as crude oil till final disposal to consumers as refined products (Reader, 2015). Scholars agree that oil rent is predominately associated with the hypothesis of 'resource curse,' from which Africa is not exempted. Resource curse is typically used to explain situations occurring in most economies that are endowed with resources but no visible improvements on their economies and governance. Such economies display tendencies to include great level of corruption, high inflation rate, unimaginable infrastructural deficit (Akanni, 2007); truncated economic growth and development (Matallah \& Matallah, 2016), pseudo-democratic system of government, internal conflict, incessant social and environmental problems (NRGI, 2015). According to the 2019 IMF Report, the African continent plays host to five out of the top thirty leading oil producing countries, accounting for 7.9 million barrels per day (representing $9.6 \%$ ) in the world. These countries are Nigeria ( 2 million barrels per day), Angola (1.4 million barrels per day), Algeria (1.3 million barrels per day), Libya (1.2 million barrels per day), and Egypt (630,000 barrels per day). Others are Democratic Republic of Congo, Gabon, Equatorial Guinea, South Sudan, Chad, Sudan and Tunisia. Virtually all these African countries are developing economies characterized by resource curse which is rooted in the 'rentier state theory.' These economies rely on international oil prices that are volatile and unpredictable, thereby hobnobbing between oil boom and down regimes.

\section{Entrepreneurial environment and institutional indicators of oil-rich African countries}

The 2017 African Economic Outlook reports that 22\% of active working population age in Africa are starting businesses with active female gender participation put at $27 \%$ and twice the number of African women who are willing to launch a start-up. The average age of early entrepreneurs is 31 years old, much younger than in East Asia ( 36 years old) and Latin America ( 35 years old). These situate African continent as having high potentials for not only genuine entrepreneurs but also industries to strive. While this statistics seems to provide heart-warming information, there are issues culminating into challenges that need to be put into proper perspective for it to be addressed, if Africa is to maintain its position with great potentials. Among these issues and challenges, the survival rate of African entrepreneurial startups is predominant. According to Gwammbuka (2019), the continent has the highest rate of small and medium enterprises' discontinuance. This is due to limited access to finance, lack of infrastructural facilities like: electricity, multiple taxes and stringent customs, and trade regulations. Lack of innovation among early entrepreneurial start-ups is a major determinant of sudden wind-up among African entrepreneurs as unexpected loss of paid unemployment is what motivated them rather than genuine entrepreneurial need to launch a startup and continuous nurture to fruition. This aligns with Kuada's opinion (2015) that mere formation of a business does not define or guarantee a genuine entrepreneur. Recently, majority of countries located within the African continent have woken up to these challenge by entrenching institutional frameworks through policy documents to back up government efforts at supporting the entrepreneurial drive among its citizens. This is consequent upon reality of the enormous potential that entrepreneurial activities offer these countries, especially when it comes to enhancing industrialization drive thereby improving on their economic growth and development.

In the institutional environment, the average institutional indicators of oil-rich countries in Africa seem to be very low. The average World Bank Governance indicators show that most of indicators are relatively low (below -0.8) over the years when compare to the benchmark of -2.5 (weak) and 2.5 (strong) (World Bank Governance Indicators, 2019). Using 2015 and 2018 figures, the political stability and absence of violence seems to be the highest (ranging between -0.70 and -0.77 ) followed by regulatory quality (about -0.63). However, the control of corruption indicator reveals most of oil rich coun- 
tries have higher level of corrupt environment (average of -0.46) and the level of accountability is relatively low (-0.41 on average). This means that all the countries have weak institutional framework which poses threat to business and entrepreneurial environment in African oil-rich countries (Ajide, 2021).

\section{Theory, previous studies, and hypotheses development}

The theory of rentier state argues that the regular external rent deriving from natural resources may give a setback for the need to have a productive domestic sector through organization of innovative entrepreneurial initiatives (Mahdavy, 1970; Beblawi \& Luciani, 1987; Le Trinh, 2019; Haque, 2020). Lack of good tax system weakens the economic system, because there may be no call for public accountability due to public distribution of wealth from natural resource such as oil rents during boom. This phenomenon distorts the institutional quality of the country leading to financial indiscipline and non-competition in other sectors of the economy. This practice brings a curse on the oil-rich countries making the institutional development to be fragile (Mustapha \& Masih, 2016). The entrepreneurial process that could improve the level of growth and innovative activities in the oil-rich economies may relatively weaken due to poor governance and rent seeking (Sachs \& Warner, 1997). Majbouri (2016) hints how the oil rent may affect entrepreneurship. Oil rents may provide an economic opportunity for the establishment of new and innovative business which improves the level of consumer earnings, thereby increasing the level of demand for products and services. However, oil rents may induce entrepreneurs to engage in rent-seeking behaviour which make them to neglect value-added activities and innovative ambitions. Oil well may be perceived by citizens to destroy formal and informal institutional structures with high social costs (Dana et al., 2009). This means that society with weak institutional environment couple with natural resource rent may have setback in it entrepreneurial start-ups (Bylund \& McCaffrey, 2017; Torres \& Godinho, 2019).

Baumol (1990) proposes that institutional system may lure economic agents to participate in nonproductive activities which account for why most oil-rich economies experienced differences in relative impact of oil rent on growth and entrepreneurial development (Williamson, 2000). The study of Torres and Godinho (2019) employs quantitative analysis to reveal that control of corruption is very important for entrepreneurial development. Moreover, Torres and Godinho explain that oil rent is not a curse if control of corruption is given serious attention. This submission is not consistent with the study of Majbouri (2016) whose results based on panel data estimation show that oil rent reduces entrepreneurship. Besides these empirical findings, it is worthwhile to verify this issue in the context of oil rich countries in Africa. This makes us propose that:

H1: Oil rent positively affects entrepreneurial start-ups in African oil rich countries.

North $(1990$, p. 3) theoretically explains that institutional quality constitutes 'the rules of the game in a given society.' This implies that it regulates contractual relationship among the economic actors in an economy (Williams, 2000; Aparicio et al. 2016). Studies suggest that availability of natural resources especially lootable ones (for instance, oil) may reallocate skills and talents to unproductive resources, thereby reducing the level of country's entrepreneurial activities (Torvik, 2002; Farzanegan, 2014). This reflects the negative impact of oil rent termed oil curse especially where there is weak institutional environment (Majbouri, 2016). Weak institutional quality enables the elites to have larger share of oil rents and distribute it to family and friends at the expenses of the large society (Badeeb et al. 2017). Corruption which is an element of institutional environment discourages entrepreneurial start-ups, because it increases transaction costs (Anokhin \& Schulze, 2009; Sekliuckiene et al., 2018). Weak institutional quality increases the level of economic uncertainty (Dreher \& Gassebner, 2013). Recent studies relate oil rent to institutional quality. Haque (2020) hints that rent seeking behaviour leads to poor institutional environment in Kingdom of Saudi Arabia. Fosu and Gafa (2019) document that improved resource rent is associated with weak institutional quality and retards productive activities. In addition, Mohammed et al. (2017) empirically explain that oil rents intensify the country's corrupt practices. Dartey-Baah et al. (2014) further highlight that political elites capitalize on weak institutional quality to misappropriate oil rents. In this case, we propose the second hypothesis: 
H2: African institutional environment negatively affects the oil rents and entrepreneurial startups relationship in African oil rich countries.

The next section explains how we tested the two hypotheses using the data of oil-rich countries in Africa.

\section{RESEARCH METHODOLOGY}

\section{Model specification}

The empirical model for investigating the causal relationship between entrepreneurial start-ups and oil rents including the interaction terms align with previous literature (Majbouri, 2016; Torres \& Godinho, 2019). The model also follows the features of panel dataset showing the cross-sections and time series data. Equation (1) shows the model specification:

$$
E P_{i t}=\beta_{0}+\beta_{1} L O I L_{i t}+\beta_{2} I N S_{i t}+\beta_{3}(L O I L \times I N S)_{i t}+\delta^{\prime} X_{i t}+\varepsilon_{i t}
$$

in which, (EP) is entrepreneurial start-ups, $i$ stands for individual country, $t$ stands for year index. LOIL stands for Oil rents (\% of GDP), INS stands for quality of institution. $X$ stands for the control variables. Control variables include; Time required to get business registered (LTM), Startup procedures (LST) and GDP growth rate (GRO). In general, the unbalanced panel data used for the estimation spanned from 2006 to 2018 covering 11 selected oil-rich countries. These countries include: Algeria, Benin, Gabon, Ghana, Mauritania, Morocco, Nigeria, Niger, South Africa, South Sudan, and Tunisia. They were selected based on data availability on the key variables of interest. Table 1 shows that our sources of data include: World Bank Development Indicators, World Bank Entrepreneurship Snapshot database and World Bank Governance Indicators (WGI). The governance data takes the lowest value of -2.5 (weak institutions) and highest value of +2.5 (strong institutions). We build the composite institutional indicators comprises the six institutional components: Control of Corruption (COR), Government Effectiveness (GOE), Political Stability and Absence of Violence (POS), Voice and Accountability (VOA), Regulatory Quality (REQ), and Rule of Law (ROL). We follow Delavallade (2006) and Adedokun (2017) and transform the institutional data into a composite index (INS) on a range of 0 (weak institutions) to 5 (strong institutions) by adding 2.5 to World Bank Institutional Indicator. We then take the average of the six indicators to have a composite index (Table 1) (Olaniyi \& Oladeji, 2020; Ajide, 2021).

Table 1. Sources of data and variable measurements

\begin{tabular}{|l|c|l|l|}
\hline \multicolumn{1}{|c|}{ Variables } & Acronym* & \multicolumn{1}{|c|}{ Measurements } & \multicolumn{1}{|c|}{ Sources } \\
\hline $\begin{array}{l}\text { Entrepreneurial } \\
\text { start-ups }\end{array}$ & $E P$ & $\begin{array}{l}\text { Number of new registered business per 1 000 adult } \\
\text { population }\end{array}$ & $\begin{array}{l}\text { World Bank Entrepre- } \\
\text { neurship Database }\end{array}$ \\
\hline Oil rent & LOIL & Oil rents expressed as percentage of GDP. Oil & World Bank Database \\
\hline $\begin{array}{l}\text { Quality of Institu- } \\
\text { tions }\end{array}$ & INS & $\begin{array}{l}\text { Average of the six governance indicators after adding } \\
2.5 \text { to make a scale, ranging from 0 (weak) to 5 (strong). }\end{array}$ & $\begin{array}{l}\text { World Governance In- } \\
\text { dicators }\end{array}$ \\
\hline economic growth & GRO & it is measured as growth rate of annual GDP per capita & $\begin{array}{l}\text { World Development } \\
\text { Indicators }\end{array}$ \\
\hline $\begin{array}{l}\text { Days required to } \\
\text { start a new venture }\end{array}$ & LTM & $\begin{array}{l}\text { Measured as the time it takes venturing activities to } \\
\text { commence expressed in days }\end{array}$ & $\begin{array}{l}\text { Doing Business indica- } \\
\text { tors }\end{array}$ \\
\hline $\begin{array}{l}\text { Number of firms' } \\
\text { registration proce- } \\
\text { dures }\end{array}$ & LST & $\begin{array}{l}\text { The number of procedures for a firm to complete for- } \\
\text { mal register in a country. }\end{array}$ & $\begin{array}{l}\text { Doing Business indica- } \\
\text { tors }\end{array}$ \\
\hline
\end{tabular}

Note: * LOIL, LTM and LST are converted to natural logarithm.

Source: own study.

In Table 2, we show the descriptive statistics of the study variables. The mean value of new business density is 2.39 per 1000 people between the age of $15-64$. This implies in a population comprises of adults, there are two persons venturing into entrepreneurial activities. The maximum number of adults engaged in business registration within the period of study is 10.38 per 1000 adults. In addition, the natural log of oil rent is 0.91 with a highest value of 4.02 . The composite institution index has a 
mean of 1.19 on a scale of zero to five. This portrays that the quality of institutions in African oildependent countries is too low.

Table 2. Descriptive statistics

\begin{tabular}{|l|c|c|c|c|c|c|}
\hline \multicolumn{1}{|c|}{ Statistics } & EP & LOIL & INS & LST & LTM & GRO \\
\hline Mean & 2.39 & 0.910 & 1.191 & 0.928 & 1.384 & 4.053 \\
\hline Median & 0.97 & 0.445 & 1.372 & 0.903 & 1.267 & 3.82 \\
\hline Maximum & 10.38 & 1.747 & 2.923 & 1.11 & 1.732 & 10.06 \\
\hline Minimum & 0.00 & 0.00 & 0.000 & 0.609 & 0.698 & -3.31 \\
\hline Std. Dev. & 3.23 & 1.065 & 1.011 & 0.379 & 1.164 & 2.82 \\
\hline Observations & 127 & 143 & 143 & 143 & 143 & 143 \\
\hline
\end{tabular}

Source: own elaboration.

The growth of these countries is about 4.05 with a maximum of 10.06 . The volatility rate is 2.82 due to frequent fluctuation in oil price in global market. The number of days for registering business and start-ups requirement is reasonably acceptable based on the criteria set by World Bank Doing Business Indicators. This development can be attributed to the doing business reforms currently taking in these countries.

\section{Derivation of marginal impacts and threshold values}

As shown in equation (1), it is very clear that oil impact on entrepreneurial activities can be directly captured through $\beta_{1}$ and indirectly captured through $\beta_{3}$. This implies that the coefficients measured the conditional impact of institutions in the relationship between oil rent and entrepreneurial start-up. In a situation of $\left(\beta_{3}>0\right)$ and $\left(\beta_{1}>0\right)$, it implies that institution complements oil rents in enhancing entrepreneurial start-ups. Meanwhile, if $\left(\beta_{3}<0\right)$ and $\left(\beta_{1}<0\right)$, it means the quality of institutions worsening the negative effect of oil rents. However, if $\left(\beta_{3}<0\right)$ and $\left(\beta_{1}>0\right)$, it means institutions weaken the positive impact of oil rents on entrepreneurial start-ups. We can also compute the marginal impact by taking the partial derivatives of equation (1) and making it equal to zero. This leads us to the computation of the institutional quality threshold value of $\left(\frac{\beta_{1}}{\beta_{3}}\right)$ (Ajide \& Osinubi, 2020; Ehigiamusoe et al., 2020).

\section{Estimation strategies}

Before we estimated the model, we examined the properties of our data via panel unit root test of Levin, et al. (2002) and Augmented Dickey Fuller (Fisher) panel unit test (Fisher, 1932). This is done to avoid spurious regression and to select appropriate estimation. After the confirmation, we employ two stage least square instrumental variables (2SLS/IV). Compared to Ordinary Least Square (OLS), 2SLS/IV is more reliable in the presence of endogeneity problem, especially when independent variables correlate with error terms. In addition, it is useful when there are feedback loops in the model. Therefore, it serves as an extension to OLS. In the implementation of IV/2SLS, we follow the procedure of Ivashina (2009) and Asongu and Tchamyou (2015). We regressed the entrepreneurial start-ups variable on its first lag. In the second stage, we used the saved fitted values as loading for the main regression (Tchamyou, 2014; Asongu \& Tchamyou, 2015; Ferede, 2019; Ajide, 2021). As a robustness check, we implemented panel correction standard error estimator (PCSE) for correction of any potential contemporaneous error.

\section{RESULTS AND DISCUSSION}

\section{Preliminary test}

In Table 3, we report the panel unit tests conducted on each variable using ADF-Fisher type and LLC tests. The tests reveal that the variables are stationary at level, meaning they have integration of order zero. 
Based on these results, testing for panel co-integration is irrelevant in this study. This justifies the appropriateness of panel least square (POLS), fixed effect (FE), IV/2SLS, and PCSE techniques.

Table 3. Panel unit root tests

\begin{tabular}{|c|c|c|}
\hline Variables & ADF Fisher-type unit-root test at level & Levin-Lin-Chu unit-root test at level \\
\hline \multirow{2}{*}{ EP } & $-4.0205^{* * *}$ & $-4.5929^{* * *}$ \\
& $(0.000)$ & $(0.000)$ \\
\hline \multirow{2}{*}{ LST } & $-7.5807^{* * *}$ & $-6.3759^{* * *}$ \\
& $(0.000)$ & $(0.000)$ \\
\hline \multirow{2}{*}{ GRO } & $-2.7203^{* *}$ & $-4.4327^{* * *}$ \\
& $(0.001)$ & $0.000)$ \\
\hline \multirow{2}{*}{ LOIL } & $-8.6864^{* * *}$ & $-5.2605^{* * *}$ \\
& $(0.000)$ & $(0.000)$ \\
\hline \multirow{2}{*}{ LTM } & $-4.8554^{* * *}$ & $-6.3597^{* * *}$ \\
& $(0.000)$ & $(0.000)$ \\
\hline \multirow{2}{*}{ INS } & $-2.4675^{* * *}$ & $-5.3926^{* *}$ \\
& $(0.000)$ & $(0.000)$ \\
\hline \multirow{2}{*}{ COR } & $-3.7920^{* * *}$ & $-2.7932^{* * *}$ \\
& $(0.000)$ & $(0.000)$ \\
\hline \multirow{2}{*}{ GOE } & $-2.6903^{* * *}$ & $-4.1861^{* * *}$ \\
& $(0.000)$ & $(0.000)$ \\
\hline \multirow{2}{*}{ POS } & $-4.1849^{* * *}$ & $-4.3565^{* *}$ \\
& $(0.000)$ & $(0.000)$ \\
\hline \multirow{2}{*}{ REQ } & $-2.5165^{* * *}$ & $-5.5058^{* * *}$ \\
& $(0.000)$ & $(0.000)$ \\
\hline \multirow{2}{*}{ ROL } & $-4.3907^{* * *}$ & $-5.0620^{* * *}$ \\
& $(0.000)$ & $(0.000)$ \\
\hline \multirow{2}{*}{ VOA } & $-8.7617^{* * *}$ & $-5.1928^{* * *}$ \\
& $(0.000)$ & $(0.000)$ \\
\hline
\end{tabular}

Note: $* * *, * *, *$ denote significance at $1 \%, 5 \%$ and $10 \%$ respectively. The null-hypothesis is that series has a common unit root. P-values are in parentheses.

Source: own study.

\section{Impact of oil rent on entrepreneurial start-ups and mediating Effect of institutions}

In most cases, it is often difficult to know the most reliable techniques to be used. This is basically due to the fact that each technique has its own strengths and weaknesses. For example, POLS technique is based on the assumption of no issue of variables' omission. This assumption is hardly met in practice. In the same vein, the panel fixed effect (FE) estimator permits shifts in intercept for individual unit in the panel. Based on these, the study reports the results from the two estimating techniques. Furthermore, there is a growing literature suggesting the probability of potential endogeneity between entrepreneurship and macroeconomic factors (Acs et al., 2012; Ferede, 2019). Failure to consider this issue may lead to fundamentally biased estimated coefficient (Adeniyi et al., 2015; Ajide, 2021). In order to address this problem, we re-estimate the model using instrumental variable estimator of two stage least square (IV/2SLS). Table 4 reports the results of the relationship between entrepreneurship, oil rent, and institutional quality in Africa.

The table 4 reveals that oil rent is positive across the estimations but not statistically significant for the case of POLS coefficient and only significant at $10 \%$ for the case of FE estimator. The coefficients of FE have substantially higher magnitudes compared to POLS. However, all the coefficients in the two estimates are lower in terms of magnitude compared with the coefficients in IV/2SLS estimated results. In addition, the coefficient of interaction term in POLS is negative, but not statistically significant while in other competing estimators (FE and IV/2SLS), the coefficients are significant. However, all the coefficients in IV/2SLS estimator are higher than those ones produced by FE. Though in terms of coefficient signs the three estimators are similar, but for obvious reasons POLS and FE estimation techniques are relatively biased and understate the coefficients of the variables. 
This may be due to variables omission, endogeneity or simultaneity biasedness. For this reason, our discussion is based on the results of IV/2SLS estimator.

Column 4 (the IV/2SLS) shows that the association between the oil rent and entrepreneurial start-ups is positive and significant irrespective of estimating techniques. Moreover, the results show that the impact of institutional quality on entrepreneurial start-up is positive and significant at $1 \%$ significance level. Specifically, a percent increase in oil rent improves the level of an entrepreneurial start-up by $7.2 \%$. This submission is consistent with the view of 'big-push' effect of natural resources, expressed in Rosenstein-Rodan (1943) and Murphy et al. (1989). It is believed that natural resource discovery or boom would offer the needed fund and physical capital to speed up the level of industrialization though business development and sustained economic activities (Sachs \& Warner, 1999). Furthermore, our results conform to the study of Okkonen and Suhonen (2010; 2013). They show that oil and gas rent improves new business set-ups and lead to an improvement in disposable income of oil rich countries. Similarly, the results suggest that the direct impact of institutional quality increases the level of entrepreneurship. Thus, a $1 \%$ increases institutional quality improves the level of business entry by $7.18 \%$. This is consistent with the confirmation of Torres and Godinho (2019). They recommend that control of corruption matters in the achievement of entrepreneurial development in the economies of oil-rich countries. However, the coefficient of interactive variables of oil rent and institutional quality is negative and significant at $1 \%$ level of significance supporting the view that government owns oil well may be lobbied by entrepreneurs who see opportunity to connect with government and weaken the institutional quality through rent seeking behaviour. These entrepreneurs further participate in unproductive activities that reduces the level of innovative output (Kolstad \& Wiig, 2009; Hodler, 2006).

In this vein, Majbouri (2016) documents that an increase in oil rent per capita diminishes entrepreneurial development in an environment with high level of corrupt practices. The coefficient of interaction terms present the case of resource curse hypothesis via governance and institutional quality, leading to reduction in the number of entrepreneurial start-ups in oil-rich African countries (Fuso \& Gafa, 2019). This is because the abundance of oil rents may bring a new political landscape for democracy with some elements of autocratic system leading to inefficient redistributive policies that weaken existing institutional quality (Auty, 2000; Sachs \& Warner, 2001; Acemoglu et al., 2004). It also means that oil rent may retard entrepreneurial start-ups indirectly through the impact of institutional quality (Isham et al., 2005; Olayungbo \& Adediran, 2017).

In fact, the conventional wisdom suggests that institutional quality should improve entrepreneurial development. This is workable on the premise of governance stability, bureaucratic quality, and absence of corruption. Meanwhile, as shown in the results, oil rent may distort the process as documented. This also reflects the view of Aparicio et al. (2016). They explain that institutional conditions perform vital roles in ascertaining whether entrepreneurial creativities would lead to productive outcomes (Baumol, 1996). Further, in oil-rich countries, the government mainly depends on oil rent to make other sectors of the economy functional. Since government is the primary receivers of rents, this oil rent has potential impact on political and other institutional structure of the economic system. Any negative shocks to the oil rent affects the institutional quality and may retard the level of entrepreneurial mindsets of citizens.

\section{Threshold of institutional factor in oil rent-entrepreneurial start-ups nexus}

Following the existing literature (Olaniyi \& Oladeji, 2020; Ajide, 2021), the institutional quality's threshold that need to be accomplished by the countries in order to gain from oil rents with respect to entrepreneurial start-up is calculated. The estimated equation (1) is differentiated with respect to LOIL (Oil rent). The resultant equation is made equal to zero to obtain the threshold level, $\frac{\partial(E P)}{\partial L O I L}=7.243-3.241 I N S=0$. Table 5 presents the marginal impacts and threshold level at which institutional context would advance African entrepreneurial activities. 
Table 4. Regression results

\begin{tabular}{|c|c|c|c|}
\hline Variables & POLS & FE & IV/2SLS \\
\hline LOIL & 0.061 & $0.431^{*}$ & $7.243^{* *}$ \\
& $(0.366)$ & $(0.054)$ & $7.183^{* * *}$ \\
\hline INS & $1.467^{* * *}$ & 1.309 & $(0.003)$ \\
\hline LOILxINS & $(0.008)$ & $(0.371)$ & $-3.241^{* * *}$ \\
& -0.045 & $-0.309 * *$ & $(0.008)$ \\
\hline LST & $(0.241)$ & $(0.024)$ & -1.463 \\
& -0.611 & $1.455^{*}$ & $(0.439)$ \\
\hline LTM & $(0.000)$ & $(0.046)$ & -1.736 \\
& $0.049 * * *$ & -0.326 & $(0.296)$ \\
\hline GRO & $(0.002)$ & $(0.588)$ & 0.327 \\
& -0.173 & -0.0059 & $(0.676)$ \\
\hline Constant & $(0.120)$ & $(0.849)$ & -8.201 \\
& $4.069 * *$ & -2.830 & $(0.221)$ \\
\hline R-squared & $(0.010)$ & $(0.398)$ & $\mathrm{n} / \mathrm{a}$ \\
\hline Wald test & 0.272 & 0.934 & 2143.803 \\
\hline$P$-value (Wald test) & 82.18 & 107.355 & 0.000 \\
\hline Hausman Test(Ch-Sq.St) & 0.000 & 0.000 & 18.394 \\
\hline Prob. (J-stat) & & $(0.005)$ & $\mathrm{n} / \mathrm{a}$ \\
\hline No. of countries & $\mathrm{n} / \mathrm{a}$ & 11 & 0.444 \\
\hline
\end{tabular}

Note: dependent variable is entrepreneurial start-ups (EP).***,**,* denote significance at $1 \%, 5 \%$ and $10 \%$ respectively. The first lag of entrepreneurial start-ups variable is used as instrument. P-values are in parentheses.

Source: own study.

Table 5. Marginal and total impacts of oil rent and threshold value of institutional quality

\begin{tabular}{|l|c|}
\hline \multicolumn{1}{|c|}{ Levels of impact } & Indicators \\
\hline Unconditional impact & $7.243^{* *}$ \\
\hline Conditional impact & $-3.241^{* * *}$ \\
\hline Threshold value for institutional quality(scale: 0 to 5) & $2.23^{* *}$ \\
\hline
\end{tabular}

Note: $* * * * *$ denote significance at $5 \%$ and $1 \%$ respectively.

Source: own study.

Table 5 shows that for oil rent to contribute meaningfully to improving the level of entrepreneurial start-ups, African oil dependent countries must setup an institutional quality framework with a threshold value of 2.23 on a five-point scale. As demonstrated in the earlier results, it is very clear that the current level of institutional quality does perform a positive role in strengthening the relationship between oil rent and entrepreneurial start-ups. It rather stunts the oil rent in the process of entrepreneurial development by playing substitutive role in the entrepreneurial process. This occurs due to weak institutional development which is below the threshold point. The current average level is 1.19 which is below the threshold value of 2.23. The oil-rich countries in Africa have a lower institutional quality which makes it hard to stimulate entrepreneurial development. Even those countries that seem to have a reasonable level of institutional quality are unable to maintain it over time. It has been established that if institutional quality is below the acceptable level, it may drag the level of growth and entrepreneurship of an economy behind the contemporaries. This submission also supports the argument of resource curse in oil rich countries explaining that rent seeking behaviour in those countries may alter and weaken the institutional structures (Frankel, 2012). It may result in negative or insignificant impact (Olaniyi \& Oladeji, 2020; Ajide \& Osinubi, 2020). However, beyond the threshold issues, oil rent has a direct positive impact on entrepreneurial start-ups. 


\section{Robustness check}

In most cases, the indicators of business environment such as time required to start business (days) and start-up procedures (number) display repeated observation on some set of countries. When estimated, this kind of data may reveal non-spherical errors. It may exhibit heteroskedasticity and contemporaneous errors across units. This makes statistical inferences from standard errors generated through ordinary least square inaccurate (Bailey \& Katz, 2011). In order to correct this potential problem, we implemented Beck and Katz (1995)'s panel-corrected standard errors (PCSE) as a robustness test reported in Table 6 . We documented some interesting results, most especially, on the coefficients of institutional requirements in establishing businesses. These include time required to start a business (LTM) and start-up procedures (LST). Their coefficients become significant at $1 \%$ significance level while other variables are also significant.

Table 6. Results of regressions on composite and individual institutional indicators (with PCSE)

\begin{tabular}{|c|c|c|c|c|c|c|c|}
\hline Variables & (1) & (2) & (3) & (4) & (5) & (6) & (7) \\
\hline LOIL & $\begin{array}{l}0.061^{* *} \\
(0.041)\end{array}$ & $\begin{array}{l}0.039 * \\
(0.087)\end{array}$ & $\begin{array}{c}0.0631^{* * *} \\
(0.014)\end{array}$ & $\begin{array}{l}-0.008 \\
(0.764)\end{array}$ & $\begin{array}{l}0.062^{* *} \\
(0.036)\end{array}$ & $\begin{array}{l}0.063^{* *} \\
(0.024)\end{array}$ & $\begin{array}{l}-0.013 \\
(0.247)\end{array}$ \\
\hline INS & $\begin{array}{c}1.467 * * * \\
(0.000)\end{array}$ & & & & & & \\
\hline LOILxINS & $\begin{array}{c}-0.045^{* *} \\
(0.021)\end{array}$ & & & & & & \\
\hline REQ & & $\begin{array}{l}1.090^{* *} \\
(0.010)\end{array}$ & & & & & \\
\hline LOIL×REQ & & $\begin{array}{l}-0.032^{*} \\
(0.094)\end{array}$ & & & & & \\
\hline VOA & & & $\begin{array}{c}0.034 \\
(0.839)\end{array}$ & & & & \\
\hline LOILXVOA & & & $\begin{array}{l}-0.022 \\
(0.185)\end{array}$ & & & & \\
\hline GOE & & & & $\begin{array}{c}0.903 * * * \\
(0.001) \\
\end{array}$ & & & \\
\hline LOIL×GOE & & & & $\begin{array}{c}0.009 \\
(0.649) \\
\end{array}$ & & & \\
\hline COR & & & & & $\begin{array}{c}3.214^{* * *} \\
(0.000)\end{array}$ & & \\
\hline LOIL×COR & & & & & $\begin{array}{c}-0.048^{*} \\
(0.066)\end{array}$ & & \\
\hline ROL & & & & & & $\begin{array}{l}0.590^{*} \\
(0.060)\end{array}$ & \\
\hline LOIL $\times$ ROL & & & & & & $\begin{array}{l}-0.040^{*} \\
(0.084)\end{array}$ & \\
\hline POS & & & & & & & $\begin{array}{c}0.270 \\
(0.178) \\
\end{array}$ \\
\hline LOIL×POS & & & & & & & $\begin{array}{l}-0.005 \\
(0.236) \\
\end{array}$ \\
\hline LST & $\begin{array}{c}-0.611^{* * *} \\
(0.000) \\
\end{array}$ & $\begin{array}{c}-0.077 \\
(0.279) \\
\end{array}$ & $\begin{array}{c}-0.660 * * * \\
(0.000) \\
\end{array}$ & $\begin{array}{c}-0.672 * * * \\
(0.000) \\
\end{array}$ & $\begin{array}{l}-0.098 \\
(0.147) \\
\end{array}$ & $\begin{array}{c}-0.653^{* * *} \\
(0.000) \\
\end{array}$ & $\begin{array}{l}-0.067 \\
(0.359) \\
\end{array}$ \\
\hline LTM & $\begin{array}{c}0.049 * * * \\
(0.000)\end{array}$ & $\begin{array}{c}0.006 \\
(0.703) \\
\end{array}$ & $\begin{array}{c}0.056^{* * *} \\
(0.000)\end{array}$ & $\begin{array}{c}0.054^{* * *} \\
(0.000)\end{array}$ & $\begin{array}{c}0.024 \\
(0.189)\end{array}$ & $\begin{array}{c}0.055^{* * *} \\
(0.000)\end{array}$ & $\begin{array}{c}0.003 \\
(0.840) \\
\end{array}$ \\
\hline GRO & $\begin{array}{c}-0.173^{* * *} \\
(0.007)\end{array}$ & $\begin{array}{l}-0.009 \\
(0.390)\end{array}$ & $\begin{array}{c}-0.183^{* * *} \\
(0.004)\end{array}$ & $\begin{array}{c}-0.171^{* * *} \\
(0.006)\end{array}$ & $\begin{array}{c}0.012 \\
(0.380)\end{array}$ & $\begin{array}{c}-0.179 * * * \\
(0.007)\end{array}$ & $\begin{array}{l}-0.007 \\
(0.445)\end{array}$ \\
\hline Constant & $\begin{array}{c}.069 * * \\
(0.002)\end{array}$ & $\begin{array}{c}2.561^{* * *} \\
(0.000)\end{array}$ & $\begin{array}{c}7.509 * * * \\
(0.000)\end{array}$ & $\begin{array}{c}7.855^{* * *} \\
(0.000)\end{array}$ & $\begin{array}{c}4.110 * * * \\
(0.000)\end{array}$ & $\begin{array}{c}7.660 * * * \\
(0.000)\end{array}$ & $\begin{array}{c}2.305 \\
(0.001)\end{array}$ \\
\hline R-squared & 0.364 & 0.237 & 0.335 & 0.354 & 0.337 & 0.338 & 0.126 \\
\hline
\end{tabular}




\begin{tabular}{|c|c|c|c|c|c|c|c|}
\hline Variables & $\mathbf{( 1 )}$ & $\mathbf{( 2 )}$ & $\mathbf{( 3 )}$ & $\mathbf{( 4 )}$ & $\mathbf{( 5 )}$ & $\mathbf{( 6 )}$ & (7) \\
\hline Wald test & 364.70 & 36.88 & 114.27 & 118.87 & 35.47 & 147.44 & 13.07 \\
\hline P-value(Wald test) & 0.000 & 0.000 & 0.000 & 0.000 & 0.000 & 0.000 & 0.001 \\
\hline No. of countries & 11 & 11 & 11 & 11 & 11 & 11 & 11 \\
\hline
\end{tabular}

Note: dependent variable is entrepreneurial start-ups (EP). Note: Control of Corruption (COR), Government Effectiveness (GOE), Political Stability and Absence of Violence (POS), Regulatory Quality (REQ), Rule of Law (ROL) and Voice and Accountability (VOA). $* * *, * *, *$ denote significance at $1 \%, 5 \%$ and $10 \%$ respectively. P-values are in parentheses.

Source: own study.

Most importantly, our variables of interest (except the estimated models that contain GOE and POS) still remain significant and have similar signs with the results generated from pooled OLS, fixed effect, and IV/2SLS. The robustness tests further support the view of Hodler (2006) who explains that resource rents offer negative pressure on institutional environment. In the same vein, Mavrotas et al. (2011) suggest that institutional quality performs a significant role in the determination of what would be the resource rent in a given economy. This means that in a society with larger presence of oil rents, the extent of institutional quality would determine whether there would be positive or negative outcomes. Therefore, the impact of oil rents will probably differ from country to country depending on the quality of institutional framework that guides governance machineries (van der Ploeg, 2011). To sum up, the coefficients of the interaction terms suggest that due to weak institutional quality of oilrich countries in Africa, oil rents become a curse to their economies.

\section{CONCLUSIONS}

This article contributes to the debates on the oil rents-entrepreneurial development nexus by investigating the role of institutional quality in the relationship. The study employs panel estimating techniques to analyse the data over a period of 2006-2018 of eleven oil-rich countries in the African continent to provide some interesting contributions to the literature and policy considerations. Firstly, the oil rent impact is positive and significant on entrepreneurial start-ups in Africa. Institutional quality impact is also positive on entrepreneurial start-ups while the interactive coefficients of oil rents and institutions have negative and significant impact on entrepreneurial start-ups. This supports the empirical work documented by a number of studies (Dwumfour \& Ntow-Gyamfi, 2018). This group of studies explains that natural resources such as oil rents might be a curse and/or a blessing to the institutional foundation of an economy. Oil rents are linked to downward pressures on quality of institutions (Hodler, 2006). This relates to the assertion that the role of potential destruction of natural resources in an economy such as rent seeking is built on the fact that oil rents are easily appropriable which leads to high rate of bribery, public policy distortions, and diversion of entrepreneurial mindsets away from productivities (Zhukova, 2006). Since it has been acknowledged in the literature that strong institutional quality plays the key role in determining whether oil rent is a curse or blessing, this study empirically develops the threshold level at which institutional conditions for oil rent can be a blessing in oil-rich African countries. The results reveal that threshold level should be 2.23 on a five-point scale. At this minimum level, institutions can forestall the potential negative impacts of oil rents on entrepreneurial start-ups.

In relation to policy perspective, this study shows that the ability of oil rents to consistently promote entrepreneurial development in oil-rich economies is conditioned on institutional context of African society. This situation may create a growth trap for African oil dependent economies in which entrepreneurial start-ups are dependent on quality of institutional foundations, which would position the growth inclusiveness and government actions on the right paths. In this context, our empirical findings suggest that African governments need to work on the institutional quality of their economies to reduce the institutional curse of oil rents on entrepreneurial start-ups. This study documents that oil rent influences entrepreneurial start-ups, but the institutions might be a curse to this impact, thereby reducing its efficacy on entrepreneurship development. Furthermore, our results reveal that business start-up regulations reduce the entrepreneurial development in Africa. In this case, reforms are needed to ensure that regulation is beneficial for the progress of entrepreneurial start-ups. 
The main limitations of the study are highlighted as follows. The first group of the limitations relates to data availability for entrepreneurship. We have only explored World Bank database on entrepreneurship which is mainly available at national level over a short period. Future studies may explore national survey data. Whenever new African datasets are available, future researchers may employ other measures of entrepreneurship including self-employment rates, Global Entrepreneurship Monitor. Moreover, they may establish business ownership rate, which, among other, is necessity and opportunity driven. Secondly, another group of our study's limitations relates to the employed econometric strategies. We are unable to replicate the results using dynamic econometric tools and its variants. This may serve as an aspiration for future studies. Finally, this study employs quantitative tools of analysis, hence, future studies may re-investigate the study's objective using qualitative analytical tools.

\section{REFERENCES}

Adedokun, A. J. (2017). Foreign aid, governance and economic growth in Sub-Saharan Africa: Does one cap fit all? African Development Review, 29(2), 184-196. https://doi.org/10.1111/1467-8268.12249.

Adeniyi, O., Ajide, K., \& Salisu, A. (2015). Foreign capital flows, financial development and growth in sub-Saharan Africa. Journal of Economic Development, 40(3), 85-103.

Adusei, M. (2016). Does Entrepreneurship Promote Economic Growth in Africa? African Development Review, 28, 201-14. https://doi.org/10.1111/1467-8268.12190.

Acemoglu, D., Verdier, T., \& Robinson, J. A. (2004). Kleptocracy and divideand- rule: A model of personal rule. Journal of the European Economic Association, 2(2-3), 162-192.

Acs , J. Z., Audretsch, D. B., Braunerhjelm, P., \& Carlsson, B. (2012). Growth and entrepreneurship. Small Business Economics, 39, 289-300. https://doi.org/10.1007/s11187-010-9307-2

Ajide, F. M. (2021): Entrepreneurship and productivity in Africa: the role of institutions, Journal of Sustainable Finance \& Investment, ahead-of-print, https://doi.org/10.1080/20430795.2021.1939645.

Ajide, F. M. \& Osinubi, T.T. (2020). Foreign aid and entrepreneurship in Africa: The role of remittances and institutional quality. Economic Change and Restructuring. ahead-of-print https://doi.org/10.1007/s10644-020-09305-5

Akanni, O. P. (2007). Oil wealth and economic growth in oil exporting African countries (The African Economic Research Consortium (AERC), AERC Research Paper 170). Kenya: AERC Publication.

Anokhin, S. \& Schulze, W.S. (2009). Entrepreneurship, innovation, and corruption. Journal of Business Venturing, 24(5), 465-476.

Aparicio, S., Urbano, D., \& Audretsch, D. (2016). Institutional factors, opportunity entrepreneurship and economic growth: panel data evidence. Technological Forecasting and Social Change, 102, 45-61.

Asongu, S. A., \& Tchamyou, V. S. (2015). The impact of Entrepreneurship on Knowledge Economy in Africa. Journal of Entrepreneurship in Emerging Economies, 8 (1), 101-131.

Auty, R. M. (2000). How natural resources affect economic development. Development Policy Review, 18(4) 347-364.

Badeeb, R.A., Lean, H.H., \& Clarck, J. (2017). The evolution of the natural resource curse thesis: A critical literature survey. Resources Policy, 51, 123-134.

Beblawi, H. \& Luciani, G. (1987). The rentier state: Nation, state and the integration of the Arab World. London: Croom Helm.

Beck, N., \& Katz, J.N. (1995). What to do (and not to do) with times-series-cross-section data in comparative politics. American Political Science Review, 89(3), 634-647.

Baumol, W.J. (1990). Entrepreneurship: productive, unproductive, and destructive. Journal of Political Economy, 98 (5) Part 1, 893-921.

Baumol, W. (1996). Entrepreneurship: productive, unproductive, and destructive. Journal of Business Venturing, 11(1), 3-22.

Bailey, D. \& Katz, J. N. (2011). Implementing panel-corrected standard errors in R: The pcse Package. Journal of statistical software, 42, 20-51. https//doi.org/10.18637/jss.v042.c01

Bustamante, C., Poblete, C., \& Amorós, J.E. (2020). Entrepreneurial intentions in the context of anatural disaster. International Journal of Emerging Markets, ahead-of-print. https://doi.org/10.1108/IJOEM-10-2019-0846 
Bylund, P.L., \& McCaffrey, M. (2017). A theory of entrepreneurship and institutional uncertainty. Journal of Business Venturing, 32(5), 461-475.

Dana, L.-P., Anderson, R.B., \& Mason, A.M. (2009). A study of the impact of oil and gas development on the dene first nations of the Sahtu (great bear lake) region of the Canadian Northwest Territories (NWT). Journal of Enterprising Communities: People and Places in the Global Economy, 3(1), 94-117.

Dartey-Baah, K., Amponsah-Tawiah, K., \& Aratuo, D. (2014). Rent-seeking resource and institutional challenges in Ghana's nascent oil economy. International Journal of Law and Management, 56(5), 363-386.

Delavallade, C. (2006). Corruption and distribution of public spending in developing countries. Journal of Economics and Finance 30: 222-239. https://doi.org/10.1007/BF02761488.

Dreher, A. \& Gassebner, M. (2013). Greasing the wheels? The impact of regulations and corruption on firm entry. Public Choice, 155(3/4), 413-432.

Dwumfour, R.A. \& Ntow-GYamfi, M. (2018). Natural resources, financial development and institutional quality in Africa: is there a resource curse? Resources Policy, 59, 411-426.

Ehigiamusoe, K.U., Lean, H. H., \& Smyth, R. (2020) The moderating role of energy consumption in the carbon emissions-income nexus in middle-income countries. Applied Energy 26(1), 114-215. https://doi.org/10.1016/j.apene rgy.2019.11421 5

Farzanegan, M.R. (2014). Can oil-rich countries encourage entrepreneurship?. Entrepreneurship and Regional Development, 26 (9/10), 706-725.

Ferede, E. (2019). Entrepreneurship and personal income tax: evidence from Canadian provinces. Small Business Economics. Retrieved from: https://doi.org/10.1007/s11187-019-00226-w on July 20, 20201

Fisher, R.A. (1932). Statistical methods for research workers. 4th Edition. Edinburgh: Oliver \& Boyd.

Fosu, A. \& Gafa, D. (2019). Natural resources, institutions and economic development in Africa. African Review of Economics and Finance, 11(1), 29-52.

Frankel, J.A. (2012). The natural resource curse: A survey of diagnoses and some prescriptions. İn: Arezki, R., Pattillo, C., Quintyn, M., Zhu, M. (eds/). Commodity price volatility and inclusive growth in low-Income Countries. United States: International Monetary Fund.

García-Cabrera, A. M. \& García-Soto, M. G. (2008). Cultural differences and entrepreneurial behaviour: An intracountry cross-cultural analysis in Cape Verde. Entrepreneurship and Regional Development, 20(5), 451-483.

Gwammbuka, T. (2019). Why Africa has the world's highest entrepreneurship and discontinuous rate. The African Exponents. Retrieved from: https://www.africanexponent.com/post/4545-the-21st-century-belongs-tothe-african-entrepreneur on January, 23.

Haque, M. I. (2020). Negating the role of institutions in the long run growth of an oil producing country. International Journal of Energy Economics and Policy, 10(5), 503-509.

Hodler, R. (2006). The curse of natural resources in fractionalized countries. European Economic Review, 50(6), 1367-1386.

Isham, J., Woolcock, M., Pritchett, L., \& Busby, G. (2005). The varieties of resource experiences: how natural resource export structures affect the political economy of economic growth, World Bank Economic Review, 19(2),23-35.

Ivashina, V. (2009). Asymmetric information effects on loan spreads. Journal of Financial Economics, 92, 300-319.

Kantis, H.D., Federico, J. S., \& Ibarra García, S. I. (2020). Entrepreneurship policy and systemic conditions: Evidence-based implications and recommendations for emerging countries. Socio-Economic Planning Sciences. ahead-of-print https://doi.org/10.1016/j.seps.2020.100872

Kolstad, I. (2007). The resource curse: Which institutions matter?. Norway: Michelson Institute Publication.

Kar,T.L. (1997), Paradox of Plenty. Oakland: University of California Press.

Kolstad,I. \& Arne W.,(2009).Itistherents,stupid!thepoliticaleconomyoftheresourcecurse. Energy Policy, 37(12), 5317-5325.

Kuada, J. (2015). Private enterprise-led economic development in Sub-Saharan Africa: the human side of growth. Berlin: Springer.

Levin, A., Lin, C.F., \& Chu, C.S.J. (2002). Unit root tests in panel data: asymptotic and finite sample properties. Journal of Econometrics, 108(1), 1-24. 
Le Trinh, T. (2019). Factors affecting startup performance of small and medium-sized enterprises in Danang city. Entrepreneurial Business and Economics Review, 7(3), 187-203. https://doi.org/10.15678/EBER.2019.070310

Mahdavy, H. (1970). The patterns and problems of economic development in rentier states: the case of Iran. In Cook, M.A. (Ed.), Studies in the Economic History of the Middle East. London: Oxford University Press.

Majbouri, M. (2016). Oil and entrepreneurship, Energy Policy, 94, 10-15.

Matallah, S., \& Matallah, A. (2016). Oil rents and economic growth in oil-abundant MENA countries: Governance is the trump card to escape the resource trap. Topics in Middle Eastern and African Economies, 18(2), 87-116.

Mavrotas, G., Murshed, S.M., \& Torres, S. (2011). Natural resource dependence and economic performance in the 1970-2000 period. Review of Development Economics, 15(1), 124-138.

Mobarak, A., \& Karshenasan, A. (2012). The impact of institutional quality on relation between resource abundance and economic growth. Iranian Economic Review, 16(32),95-110.

Mustapha, I.M. \& Masih, A.M. (2016). Dutch disease or Nigerian disease: A prima facie? New evidence from ARDL bound test analysis. Working Paper, MPRA Paper 69767. Germany: University Library of Munich Publication

Mohammed, C. S., Mohamed, B., \& Abderrahim, C. (2017). Oil rents and institutional quality: empirical evidence from Algeria. Topics in Middle Eastern and African Economies Proceedings of Middle East Economic Association, 19(2), 1-31.

Murphy, K. M., Shleifer, A., \& Vishny, R. W. (1989). Industrialization and the big push. Journal of Political Economy, 97(5), 1003-1026.

North, D.C. (1990). Institutions, institutional change and economic performance. Cambridge: Cambridge University Press.

Okkonen, L. \& Suhonen,N. (2010). Business models of heat entrepreneurship in Finland. Energy Policy 38(7), 3443-3452.

Okkonen, L. \& Suhonen, N. (2013). The energy services Company (ESCo) as business model for heat entrepreneurship: a case study of North Karelia, Finland. Energy Policy, 61, 783-787.

Olaniyi O. C. \& Oladeji , S.I. (2020) Moderating the effect of institutional quality on the finance-growth nexus: insights from West African countries. Economic Change \& Restructuring, ahead-of-print https ://doi.org/10.1007/s1064 4-020-09275-8

Olayungbo, D.O. \& Adediran, K.A. (2017). Effects of oil revenue and institutional quality on economic growth with an ARDL approach. Energy and Policy Research, 4(1), 44-54.

Peprah, A.A. \& Adekoya, A. F. (2020). Entrepreneurship and economic growth in developing countries: Evidence from Africa. Business Strategy and Development, ahead-of-print, DOI: 10.1002/bsd2.104.

Reader, N. R. G. I. (2015). The resource curse: The political and economic challenges of natural resource wealth. USA: Natural Resource Governance Institute.

Rosenstein-Rodan, P. N. (1943). Problems of industrialisation of Eastern and South-eastern Europe. The Economic Journal, 53(210/211), 202-211.

Sachs, J. D. \& Warner, A. M. (2001). The curse of natural resources. European Economic Review, 45, 827-838.

Sachs, J.D. \& Warner, A.M. (1997), Natural Resource Abundance and Economic Growth. Center for International Development and Harvard Institute for International Development. Cambridge, MA: Harvard University.

Sekliuckiene, J., Vaitkiene, R., \& Vainauskiene, V. (2018). Organisational Learning in Startup Development and International Growth. Entrepreneurial Business and Economics Review, 6(4), 125-144. https://doi.org/10.15678/EBER.2018.060407

Tchamyou, S. V (2014). The role of knowledge economy in African business. HEC-Management School. Liege: University of Liege.

Torres, P., \& Godinho, P. (2019). Opportunity entrepreneurship, oil rents and control of corruption. Journal of Enterprising Communities: People and Places in the Global Economy, 13(5),647-667. DOI 10.1108/JEC-07-2019-0067

Torvik, R. (2002). Natural resources, rent-seeking and welfare. Journal of Development Economics, 67(2), 455-470.

Van der Ploeg, F. (2011). Natural resources: curse or blessing. Journal of Economic Literature, 49(2), 366-420.

Williamson, O.E. (2000). The new institutional economics: taking stock, looking ahead. Journal of Economic Literature, 38(3), 595-613.

Yates, D. A. (2015). The rise and fall of oil-rentier states in Africa. London: Palgrave Macmillan. 
Zhukova, N. (2006). Resource abundance and economic growth: the role of institutional development, Working paper \#BSP/2004/071E, Moscow: New Economic School Publication.

\section{Authors}

The two authors contributed to the study equally. Folorunsho M. Ajide developed the concept notes, wrote the introduction, methodology, analyzed the data, and formulated conclusion. Kenny A. Soyemi wrote literature review, collected data, interpreted the results, and proofread.

\section{Folorunsho M. Ajide}

Lecturer in Economics, Faculty of Social Sciences, University of llorin, Ilorin, Nigeria. PhD in Economics from Obafemi Awolowo University, Ile-Ife, Nigeria. His research interest includes economics of entrepreneurship, economics of crime, industrial and financial economics.

Correspondence to: Dr. Folorunsho M. Ajide, P.M.B. 1515, llorin, Kwara State, Nigeria; e-mail: ajide2010@gmail.com or/ and ajide.fm@unilorin.edu.ng

ORCID ๑ http://orcid.org/0000-0003-3231-2423

\section{Kenny A. Soyemi}

Lecturer in the Department of Accounting, Faculty of Administration and Management Sciences, Olabisi Onabanjo University, Ago-Iwoye, Nigeria. PhD in Accounting from Obafemi Awolowo University, lle-Ife, Nigeria. His research interest includes entrepreneurial finance, financial reporting, audit and assurance, taxation and fiscal policy.

Correspondence to: Dr. Kenny A. Soyemi, P. O. Box 151, ljebu-lgbo, Ogun State, Nigeria; e-mail: kenny_ade.soyemi@oouagoiwoye.edu.ng

ORCID $\odot$ http://orcid.org/0000-0002-9244-2679

\section{Acknowledgements and Financial Disclosure}

The authors would like to thank the editors of this journal and the anonymous referees for their useful comments, which have been used to improve the quality of this article. The authors declare that they not receive any financial support in respect of this research.

\section{Conflict of Interest}

The authors declare that they do not have any conflict of interest in respect of this research.

\section{Copyright and License}

This article is published under the terms of the Creative Commons

Attribution - NoDerivs (CC BY-ND 4.0) License

http://creativecommons.org/licenses/by-nd/4.0/ 
